\title{
THE LIBRARY OF THE SCHOOL OF MANAGEMENT AND LABOR RELATIONS AT RUTGERS UNIVERSITY: A RESOURCE TO NEW JERSEY AND BEYOND
}

\author{
BY JEFFREY P. KATZ
}

Mr. Katz is a Librarian at the SMLR Library, Rutgers University.

\section{Background and Mission}

The School (formerly the Institute) of Management and Labor Relations (SMLR) was founded in 1947 by an Act of the New Jersey Legislature, to "foster harmony between labor and management." Its mission is to improve knowledge and practice within the areas of labor relations, industrial relations, and human resource management. ${ }^{2}$ The School is composed of three departments: Human Resource Management, Labor Studies and Employment Relations, and Library and Information Services. The Rutgers undergraduate colleges offer a B.A. in Labor Studies; and the School awards the Master's Degree in Labor and Industrial Relations, the M.S. in Human Resource Management, and the Ph.D. in Industrial Relations and Human Resources. In 1991, the School also began offering the M.S. in Human Resource Management in cooperation with the Singapore Institute of Management. ${ }^{3}$

The SMLR Library acts as a center for acquiring, organizing and disseminating information on labor, industrial relations and human resource management.

Its mission is to:

1) provide services and develop collections in support of the School's credit programs;

2) provide library and information services to the School's continuing education (non-credit) programs;

3) maintain the School's archives and work cooperatively with Special Collections/Archives at the Rutgers University Alexander Library in New Brunswick in obtaining labor management archival materials; and

4) provide broad-based reference, research, and referral services to scholars, labor and industrial relations practitioners, and to workers throughout New Jersey and beyond. 


\section{Collections}

The Library's collections include materials in a wide variety of formats on such topics as: benefits and compensation; collective bargaining and contracts; comparative industrial relations; employee ownership; human resource management; labor disputes; labor history; labor law; labor statistics; labor unions; minority/migrant workers; occupational and personnel psychology; organizational behavior; safety and health at work; social security; wages/hours/working conditions; women workers; work and family; workers' compensation; workforce diversity.

\section{Monographs}

The Library holds some 5,000 monographs and monographic sets, offering both practical information to the worker and manager, and theory to the scholar. The scope of the collection is shown by the following representative titles: Analyzing Safety Performance; The Asian Century: the Economic Ascent of the Pacific Rim and What It Means for the West; Benefit-Cost Analysis for Program Evaluation; Black Women in the Workplace; The Black Worker: a Documentary History from Colonial Times to the Present (8 vols.); Decisions in Organizations; Drafting the Union Contract: A Handbook for the Management Negotiator; Employee Stock Owenership and Related Programs; Employers' Guide to Workers' Compensation; How To Manage with a Union; The Human Resource Yearbook; The Japanization of British Industry; Management of Human Resources: Concepts for Developing Nations; New Jersey Employment Law; Pay Equity in the Public Sector, 1979-1989; Techniques of Mediation; Unjust Dismissal (2 vols.); Women and Trade Union in Eleven Industrialized Countries; and Worker Protection, Japanese Style.

\section{Periodicals Collections}

There are three distinct collections of periodicals at the library. The Periodicals collection proper includes approximately 150 titles of both scholarly (Labor Studies Journal) and popular (New Jersey Business) periodicals. The Union Newsletter Collection contains more than 100 current subscriptions to New Jersey, U.S., and foreign trade union organs, (e.g., AFL-CIO News and Locomotive Engineers' Journal). The News Services Collection, consisting of 15 titles, provides reports and analyses on current labor-management issues. Examples include: BNA's Daily Labor Report, HR Reporter, Benefits and Pensions Reporter, NLRB Weekly Summary of Cases; Labor Relations Week; and the Worker's Compensation Report.

\section{Print Services}

Our "Print Services" are looseleaf-bound, regularly-updated sources of information that provide subject access to such issues as occupational 
safety, labor law, human resource management and industrial relations, and include some titles unique in the Rutgers libraries system.

Print Services offer an elegant method for searching policies, laws, court cases, and arbitrations by subject. As an example, the Labor Relations Reporter $(L R R)$, unique in the Rutgers University libraries system at the SMLR Library, is a set of volumes that covers, from the mid-1930s, the whole gamut of labor law, policies and practices. The $L R R$ can be searched by the names of the appellants in a case by using the "Tables of Cases" in each reporter, or by subject by using the Master Index. The set includes Manuals, Case Reporters, and News/Analysis.

The Manuals contain texts of statutes, and narratives on policies and practices at the workplace; and the Case Volumes and their indexes called CDIs (see below) contain court cases and arbitrations that the editors of the Reporter deem significant. The News/Analysis volumes provide updates on new developments.

The $L R R$ contains five manuals: Fair Employment Practices, Individual Employment Rights, Labor Relations Expeditor, State Labor Laws, and Wages and Hours; and six case volumes: Americans with Disabilities, Fair Employment Practices, Individual Employment Rights, Labor Arbitration Reports, Labor Relations Reference Manual [a misnomer, in that it is not a "Manual" at all, but a "Case Volume" containing the full texts of cases on labor law not included in any of the other Case volumes, as well as decisions of the NLRB], and Wages and Hours.

The Labor Relations Expeditor is a special 2-volume set that affords an overview of a subject, complete with references to the other reporters. It is one of the best reference sources to begin a subject search.

The SMLR Library also holds other print services which use the same methodology. Their variety is illustrated by a sample of titles: Executive Compensation; HR Policies and Practices; Termination of Employment, Job Safety and Health; The Americans with Disabilities Act Manual (different from the volume of the LRR); and Collective Bargaining, Negotiations and Contracts, which provides a subject approach to the contract language of over 400 private-sector labor contracts.

\section{The Subject File}

Since the mid-1970s the library has collected fugitive materials (ephemera, pamphlets, manuals, reprints, clippings, reports) on labor-management issues in its Subject File, materials not ordinarily found in IRIS, the Rutgers online catalog, and arranged by Subject Heading according to a set of locally-developed terms. In 1993, the library developed a PC-based online catalog, "IMLRCAT," (now "SMLRCAT") with which these materials can be searched by keyword. The "New Subject File" now consists of over 500 items, to which materials in the "Old Subject File" are being converted. 


\section{Labor Materials Collections}

In cooperation with the New Jersey Public Employee Relations Commission (PERC), the library is the official depository for New Jersey Public Sector Labor Contracts. Each year, every public sector employer in the State receives a mailing from PERC and the SMLR Library, reminding them that they are by law (N.J.S.A. 34:13A-8.2) required to send us copies of each labor contract they negotiate. Initiated in the 1970 s, this collection includes more than 2,000 current contracts represented in SMLRCAT. The library is also a depository for New Jersey PERC decisions, including Interest Arbitration Decisions and those of the Director of Unfair Practices and the Director of Representation.

In addition, the library owns a collection of selected Private Sector Labor Contracts. More information on the content of private-sector contracts may be gleaned from BNA's Collective Bargaining, Negotiations and Contracts. Other important resources are a collection of Union Constitutions and Conference Proceedings, and of relevant New Jersey and Federal Government Documents, including reports from the New Jersey Departments of Civil Service and Labor on economic indicators and population.

\section{Audio-Visual Collection}

The SMLR Library's A/N collection consists of some 250 items in a variety of formats, including $16 \mathrm{~mm}$. films, audiotapes, recordings, and VHS and Betamax videocassettes. Subjects range from labor history and grievance and arbitration procedures to management training. Titles include "Anatomy of a Grievance," "How to Avoid the 16 Leading Causes of OSHA Citations," "Labor and the War Effort," "Employing the Disadvantaged" and "1877: the Grand Army of Starvation." Materials may be viewed onsite for a nominal fee. The Library also rents Audio-Visual equipment to nonSMLR individuals and groups for use in the Labor Education Center. Arrangements can be made for the use of $\mathrm{A} / \mathrm{V}$ equipment in rooms reserved at the Labor Education Center for this purpose.

\section{Archival Collections}

The library possesses a rich archive that includes faculty papers and IMLR's Founding Papers. One of our most treasured holding is that of the papers of the Affiliated Schools for Workers, including the Bryn Mawr Summer School for Women Workers.

Under the CAPES ("Caucus Archival Projects Evaluation Service) Program of the New Jersey Historical Commission, the collection was recently appraised by Mr. Gary Saretzky as follows: 
[T] The Affiliated Schools for Workers, Inc. (ASW) . . operated educational programs from 1921 to ca. 1950. The School had the financial backing of major labor unions in the garment industry and, in the 1930s, the WPA. Its honorary trustees in the 1940s included Eleanor Roosevelt (chair) and Walter Reuther. Supported by the moderate elements in the labor movement, the School offered an alternative to educational programs of the communists and socialist workers.

The Bryn Mawr Summer School for Women Workers was the first program of its kind in the United States [and] brought garment workers to Bryn Mawr College for two months. This school moves about 1950 and became the Hudson Shore Labor School in West Park, New York.

[The Bryn Mawr Summer School] has been the subject of a recent film, "Women of Summer" [and of numerous books and articles].... The records of the ASW at IMLR appear to be the surviving office files of the Hudson Shore Labor School, including the records of its predecessor, the Bryn Mawr School for Women Workers. Included are some materials pertaining to the other schools of the ASW. Much of the material consists of curriculum materials [and] other activities of the students ... [who], for example ..., organized a boycott of a racially segregated luncheonette in 1934. Publicity files contain a wealth of information about the programs of the ASW.

The collection consists of hand-written, type-written, printed, photographic (including panoramic photographs), and film materials, and remains in "excellent shape." 4

\section{Online Resources}

The library provides access to SMLR faculty and students for courserelated research to $L E X I S / N E X I S \odot$, one of the largest and most varied sources of electronic information in the world. It contains, often in full text, such things as: a Supreme Court decision from 1791; last night's MacNeilLehrer Nereshour; a law review article on the increasing use of Yiddish in court decisions; or a list of articles on child-care programs among government employees.

$H R I N \bigcirc$, the "Human Resources Information System," a smaller family of databases, also contains many daily reporters, as well as an online version of the Labor Relations Reporter. The Census 1990 database allows users to customize tables of statistics.

The library also has access to DIALOG@, another large and varied online service, the use of which may require a fee. 
As a part of the Rutgers libraries system, access is provided to INFO, the Rutgers Information System, which now connects to the World Wide Web and also contains numerous databases valuable for our subject specialty. In addition, we offer access to the Rutgers Mainframes, and support for $S A S \subseteq$, a mainframe-based statistics program.

Finally, the SMLR Library is the home of CIRLNET, a nationally distributed listserv (electronic discussion list) for the Community of Industrial Relations Librarians. CIRLNET serves as a forum for anyone interested in Industrial Relations. Those with access to the Internet can subscribe by sending electronic mail to:

LISTSERV@RUTVM1.RUTGERS.EDU

and putting in the body of the mail:

SUBSCRIBE CIRLNET your full name

\section{Library Services}

Access

The library's monographs and periodical collections are fully represented in IRIS, the Rutgers Online Catalog, and in Innopac, the Rutgers Monograph ordering and Serials Check-in system. Our holdings bear the location IMLR. Both are available free to the public in the library's "Information Arcade," which also provides access to other electronic resources at Rutgers. The Subject File, A/V Catalog, and the Public Sector Contracts Collection are all represented in SMLRCAT, the library's PCbased catalog, available only at the SMLR Library.

Although books may be checked out, issues of periodicals, Subject File materials, Labor Contracts, and items marked "REFERENCE" do not circulate.

\section{Ready Reference}

The library offers free Ready Reference services for anyone calling or visiting. These requests can be anything from finding a fugitive statistic to determining when the first "Labor Day" was celebrated. ("The Central Labor Union of New York initiated the practice of making the first Monday in September Labor Day in 1882," though President Cleveland didn't adopt the bill, "drawn up by the A. F. of L. to make it a national holiday until June 28, 1894." )

\section{Extended Reference}

More extensive reference services, including, when appropriate, the employment of online resources, are offered free to our faculty and students. The library also provides extended reference support to non-Rutgers individuals and businesses through our SMLRAccess Program, a for-fee 
reference service that can include online searching. These questions may involve such projects as listing citations for labor contracts in New Jersey for EMTs; or compiling a table showing the numbers, by sex and race, of New Jersey lawyers, or of any industry, occupation, or location.

\section{Support for Collective Bargaining}

The library believes that providing complete information to both sides is crucial to successful collective bargaining, and it offers both management and labor a suite of services designed to provide information and improve communication between them. To support public-sector bargaining, we own such titles as the Index and Analysis of Public Employment Relations Commission Decisions, the New Jersey Public Employee Reporter, the National Public Employee Reporter, and the Negotiations Data Sourcebook produced by the New Jersey School Boards Association. The $L R R$ contains a great deal of use to management and labor in the private sector.

\section{Conclusion}

In the face of developing economic realities and new structures of work, the question of whether labor unions can continue in their traditional role as agents of collective bargaining "against" management, or will instead transform themselves into something entirely new, remains open. What is clear is that a crisis exists in the labor movement and that the SMLR Library will continue to play its historic role in "fostering cooperation," bringing needed information and knowledge to all so all can benefit.

\section{NOTES}

1. Portions of this article were previously published in Nese Jersey Libraries (Winter, 1993/4), p. 25-7.

2. 1947 New. Jersey Iaws 307.

3. The Singapore Institute of Management, "SIMI," founded in 1964, offers a wide range of Masters programs in such areas as Business Information Technology, Finance, Business Administration, Education, and Accounting, as well as Human Resource Management. It also offers numerous Graduate Diploma, B.A., Diploma, and Certificate programs. Aside from the SMLR, other institutions offering degrees through the SIM include the University of West London, the University of London, the Institute of Training and Development [UK], and the Royal Melbourne Institute of 'Technology.

4. Saretzky, Gary, "CAPES Report, IMLR Library," 20 February, 1994.

5. Foner, Philip S., History of the Labor Movement in the United States (New York: International Publishers, 1955), II: 33, 96. 